\title{
Research Article: Constraints in adoption of moth production technology in arid zone of Rajasthan
}

\author{
Ramdhan Ghaswa, S.K. Sharma, S.S. Bana and Amit Kumar
}

Article Chronicle : Received :

22.02.2018;

Revised :

19.03.2018;

Accepted :

05.04.2018

KEY WoRds :

NFSM, Beneficiary, Non-beneficiary
Author for correspondence :

\section{Ramdhan Ghaswa}

Directorate of

Extension Education,

S.K. Rajasthan

Agricultural University,

Bikaner (Rajasthan)

India

Email:ghaswaextension@ gmail.com

See end of the article for authors' affiliations
SUMMARY : The present study was conducted in Bikaner district of Rajasthan. The National Food Security Mission is in operation in all six Panchayat samities of Bikaner district. Out of which fifty per cent Panchayat samities, i.e. three Panchayat samities Nokha, Lunkarnshar, Sri Dungargarh were selected purposely. Out of selected Panchayat samities three Gram Panchayats were selected randomly from each Panchayat samities on the basis of random sampling method. Thus, the total 9 villages were selected. To know the impact of National Food Security Mission, a control group of villages were also be required. Therefore, three distant villages where the National Food Security Mission was not in operation were also selected on the basis of random sampling technique from each identified Panchayat Samiti. 7 beneficiary and 7 non-beneficiary Gram respondents were selected randomly from each identified village. Thus, a total of 63 beneficiary respondents and 63 non-beneficiary Gram respondents were selected. The study revealed that lack of skill about application of chemicals, inadequate knowledge about soil treatment, unavailability of bio-fertilizers at village level, timely unavailability of seed minikits at local level, lack of skill about plant protection measures, lack of technology guidance at proper time, unavailability of plant protection equipments, improper knowledge of micro-nutrient application, nepotism and favoritism in distribution of minikits under NFSM and high cost of improved seeds, micro-nutrients, fungicides were important constraints.

How to cite this article : Ghaswa, Ramdhan, Sharma, S.K., Bana, S.S. and Kumar, Amit (2018). Constraints in adoption of moth production technology in arid zone of Rajasthan. Agric. Update, 13(2): 143-146; DOI : 10.15740/HAS/AU/13.2/143-146. Copyright@2018: Hind Agri-Horticultural Society. 